\title{
Az európai nyomozási határozat mint a büntetőeljárás hatékonyságát fokozó eszköz
}

\author{
büntetöügyekben folytatott igazságügyi együttmüködés az Európai Unióban - \\ kölcsönös elismerés elve - \\ európai nyomozási határozat - bizonyítékszerzés - \\ bizonyítási eszközök átadása
}

A büntetőügyekben folytatott igazságügyi együttműködés egyik célkitűzése egy olyan eljárási rendszer kidolgozása, amely elősegíti a tagállami büntetőeljárások hatékonyságát, így lehetőséget teremt arra, hogy az egyik tagállamban beszerzett bizonyítási eszköz egy másik tagállamban folytatott büntetőeljárás keretében is könnyedén felhasználható legyen. ${ }^{1}$ Az Amszterdami Szerződés hatálybalépésétől kezdődően több olyan dokumentum is született, amelyik egy ilyen rendszer megteremtésének szükségességére hívta fel a figyelmet. ${ }^{2} \mathrm{Az}$ Európai Bizottság (a továbbiakban: Bizottság) 2009-ben kiadott, a büntetöügyekben felvett bizonyítékoknak

* Dr. Jánosi Andrea egyetemi adjunktus, Miskolci Egyetem Állam- és Jogtudományi Kar, Bűnügyi Tudományok Intézete, Miskolc. E-mail: jogandi@uni-miskolc.hu. A tanulmányban ismertetett kutatómunka az EFOP3.6.1-16-00011 jelü „Fiatalodó és megújuló egyetem - Innovatív Tudásváros - a Miskolci Egyetem intelligens szakosodást szolgáló intézményi fejlesztése" projekt részeként - a Széchenyi 2020 keretében - az Európai Unió támogatásával, az Európai Szociális Alap társfinanszírozásával valósul meg.

1 A büntető igazságszolgáltatás hatékonyságának követelménye, hogy egyszerű, gyors, alapos, költségkímélö, az alkalmazott büntetőjogi szankcióknak pozitív, megelőző hatása van a bủncselekmények alakulására. Lásd FARKAS Ákos: A falra akasztott nádpálca - avagy a büntető igazságszolgáltatás hatékonyságának korlátai. Osiris, Budapest, 2002, 98; FANTOLY Zsanett: Hatékonysági problémák, azaz a hazai büntetőeljárás gyakorlati visszásságai. Acta Universitatis Szegediensis: Acta juridica et politica, Tom. 74., 2012, 119; A büntetőügyekben a hatékonyság növelését társadalmi követelményként és jogalkotói célként is aposztrofálják. Lásd HACk Péter-HoRvÁTH Georgina: A büntetőeljárás egyszerűsítésének lehetőségei és korlátai. In: Finszter Géza-Kőhalmi László-Végh Zsuzsanna (szerk.): Egyre jobb világot hátrahagyni... Tanulmányok Korinek László Professzor tiszteletére. Pécsi Tudományegyetem Állam- és Jogtudományi Kar, Pécs, 2016 , 300.

2 A tamperei következtetések: Az Európai Tanács 1999. október 15-16-i ülése, Az elnökség következtetései SN 200/1/99 REV 1.; A kölcsönös elismerés elvének végrehajtásáról szóló intézkedési program: Intézkedési program a büntetöügyekben hozott határozatok kölcsönös elismerése elvének végrehajtására. HL C 12 , 2001.01.15., 10; Hágai program: a szabadság, a biztonság és a jog érvényesülésének erősítése az Európai Unióban. HL C 53, 2005. 03. 03., 1; A Tanács és a Bizottság cselekvési terve az Európai Unióban a szabadság, a biztonság és a jog érvényesülése megerősítéséről szóló hágai program végrehajtásáról. HL C 198, 2005. 08. 12., 1. A Bizottság Közleménye a Tanácsnak és az Európai Parlamentnek - A szabadság, a biztonság és a jog érvényesülésén alapuló térség a polgárok szolgálatában. COM/2009/0262 végleges. 
a tagállamok által másik tagállamtól történő megszerzéséröl és elfogadhatóságuk biztosításáról szóló Zöld könyvében számba vette azokat a hatályos jogintézményeket, amelyek „mechanizmusokat biztosítanak a tagállamok számára ahhoz, hogy a határokon átnyúló helyzetekben elfogadható büntetöügyi bizonyítékokat gyüjtsenek", s megállapította, hogy a bizonyításfelvételt érintő uniós joganyag alapvetően két csoportra osztható. Vannak egyrészt olyan jogintézmények, amelyek kölcsönös jogsegélyre (pl.: kölcsönös bűnügyi jogsegélyről szóló európai egyezmény), ${ }^{3}$ másrészt pedig olyanok, amelyek a kölcsönös elismerés elvére épülnek (pl.: európai bizonyításfelvételi parancs). ${ }^{4}$ Valójában egyik sem teremti meg azt a mechanizmust, amellyel biztosított lenne a hatékony bizonyításfelvétel egy másik tagállamban, vagy a megszerzett bizonyítási eszközök tényleges felhasználhatósága/elfogadhatósága. ${ }^{5} \mathrm{E}$ hiányosság kiküszöbölését hivatott szolgálni a 2014. április 3-án elfogadott európai nyomozási határozatról szóló irányelv. ${ }^{6}$ Célkitűzése - a büntetőeljárások hatékonyságának a fokozása érdekében - a bizonyításfelvétel és a bizonyítékátadás egységes, a kölcsönös elismerés elvén alapuló rendszerének megteremtése, ${ }^{7}$ amely a bizonyítékok minden fajtájára kiterjed, pontos végrehajtási határidőket jelöl meg, és szük körre korlátozza a megtagadás lehetséges indokait. ${ }^{8} \mathrm{Az}$ európai nyomozási határozat (a továbbiakban: ENYH) az alábbi jogintézmények felváltását szolgálja: a kölcsönös jogsegélyen alapuló eszközök közül a Kölcsönös bünügyi jogsegélyről szóló európai egyezményt és kiegészítő jegyzőkönyveit; a Schengeni Végrehajtási Egyezményt, az Európai Unió tagállamai közötti kölcsönös bünügyi jogsegélyről szóló egyezményt és kiegészítő jegyzőkönyvét, és bi- és multilaterális megállapodásokat. ${ }^{9} \mathrm{~A}$ kölcsönös elismerés elvén alapuló eszközök közül az európai

3 Az 1959. április 20-i európai egyezmény a kölcsönös bünügyi jogsegélyről, valamint 1978. és 2001. évi kiegészítő jegyzőkönyvei; Schengeni Végrehajtási Egyezmény (Egyezmény a Benelux Gazdasági Unió Államai, a Németországi Szövetségi Köztársaság és a Francia Köztársaság kormányai között a közös határaikon történő ellenőrzések fokozatos megszüntetéséröl 1985. június 14-én kötött Schengeni Megállapodás Végrehajtásáról); Az Európai Unió tagállamai közötti kölcsönös bűnügyi jogsegélyröl szóló, 2000. május 29-én kelt egyezmény (A Tanács jogi aktusa [2000. május 29.] az Európai Unió tagállamai közötti kölcsönös bünügyi jogsegélyegyezménynek az Európai Unióról szóló szerződés 34. cikke szerinti létrehozásáról. HL C 197, 2000. 07. 12. és Jegyzőkönyv a Tanács által az Európai Unióról szóló szerződés 34. cikkének megfelelöen létrehozott, az Európai Unió tagállamai közötti kölcsönös bűnügyi jogsegélyröl. HL C 326, 2001. XI. 21., 2-8.)

4 A Tanács 2008/978/IB kerethatározata (2008. december 18.) a büntetőeljárások során felhasználandó tárgyak, dokumentumok és adatok megszerzéséhez szükséges európai bizonyításfelvételi parancsról. HL L 350, 2008. XII. 30., 72-92. (A továbbiakban: a Tanács 2008/978/IB kerethatározata.)

5 Zöld könyv a büntetőügyekben felvett bizonyítékoknak a tagállamok által másik tagállamtól történő megszerzéséröl és elfogadhatóságuk biztosításáról. 2009.11.11. COM/2009/0624 végleges.

6 Az Európai Parlament és a Tanács 2014/41/EU irányelve (2014. április 3.) a büntetőügyekben kibocsátott európai nyomozási határozatról. HL L 130, 01/05/2014, 1-36. (A továbbiakban: ENYH irányelv.)

7 BelfIORE, Rosanna: Critical Remarks on the Proposal for a European Investigation Order and Some Considerations on the Issue of Mutual Admissibility of Evidence. In: Ruggeri, Stefano (ed.): Transnational Evidence and Multicultural Inquires in Europe. Developments in EU Legislation and New Challenges for Human Rights-Oriented Criminal Investigations in Cross-border Cases. Springer, Cham-Heidelberg-New York-Dordrecht-London, 2014, 93.

8 ENYH irányelv (6) preambulumbekezdés.

9 Az ENYH irányelv 34. cikk (1) és (3) bekezdései alapján 2017. május 22-i hatállyal az ENYH irányelv felváltja az irányelv hatálya alá tartozó tagállamok közötti kapcsolatokra alkalmazandó, fent megjelölt egyezmények 
bizonyításfelvételi parancsról szóló kerethatározatot, valamint a vagyonnal vagy bizonyítékkal kapcsolatos biztosítási intézkedést elrendelő határozatok végrehajtásáról szóló kerethatározatot váltja fel. ${ }^{10}$

A fentiek mellett további kölcsönös bünügyi jogsegélyegyezmények születtek az EU és harmadik országok között, így Japánnal ${ }^{11}$ és az Egyesült Államokkal. ${ }^{12}$

A tagállamoknak az európai nyomozási határozatra vonatkozó uniós szabályokat 2017. május 22-ig kellett átültetniük a nemzeti jogrendszerükbe. (Magyarország 2017. május 23-i időponttal tett eleget ennek a kötelezettségének. ${ }^{13}$ Az Európai Bizottság 2017 júliusában felszólító levelet küldött a beillesztéssel késlekedő tagállamoknak, amelyben felhívta a figyelmüket arra, hogy amennyiben két hónapon belül nem teszik meg a szükséges lépéseket, az Európai Unió Bírósága elé terjesztheti az ügyet. A Bizottság négy tagállam esetében sürgette a bizonyítékok EU-n belüli cseréjének megkönnyítésére irányuló szabályok átültetését, így 2018 januárjában indokolással ellátott véleményt küldött Ausztriának, Bulgáriának, Luxemburgnak és Spanyolországnak, ugyanis addig még nem illesztették be nemzeti jogukba az európai nyomozási határozatra vonatkozó uniós szabályokat. ${ }^{14} 2018$. december 14-i vizsgálat alapján azonban már a megjelölt tagállamok (Ausztria 2018. július 1-jén, Bulgária 2018. február 23-án, Luxemburg 2018. szeptember 15-én, Spanyolország 2018. július 2-án) is teljesítették az implementálásra irányuló feladataikat. ${ }^{15}$

megfelelő rendelkezéseit, azzal a megkötéssel, hogy az említett rendelkezések a tagállamok és harmadik államok közötti kapcsolatokra továbbra is alkalmazandók. Az ENYH irányelv tehát a joghézagok elkerülése érdekében nem bocsátkozik azon konkrét cikkek felsorolásába, amelyek helyébe az ENYH irányelv vonatkozó rendelkezései lépnek. Emellett „a tagállamok 2017. május 22. után más tagállamokkal csak akkor köthetnek vagy alkalmazhatnak tovább két- vagy többoldalú egyezményeket és megállapodásokat, ha azok lehetővé teszik ezen irányelv céljainak további megerősítését, és hozzájárulnak a bizonyitékgyüjtési eljárások egyszerüsitéséhez vagy további megkönnyítéséhez, valamint feltéve, hogy tiszteletben tartják az ezen irányelvben foglalt biztosítékok szintjét”. Lásd Javaslat - Az Európai Parlament és a Tanács irányelve az európai bủnügyi nyomozati parancsról. Indokolás, Brüsszel, 2010. június 3. 9288/10 ADD 1. 29. cikk.

10 A Tanács 2003/577/IB kerethatározata (2003. július 22.) a vagyonnal vagy bizonyítékkal kapcsolatos biztosítási intézkedést elrendelő határozatoknak az Európai Unióban történő végrehajtásáról. HL L 196, 2003. 08. 02., 45-55.

11 Megállapodás az Európai Unió és Japán között a kölcsönös bűnügyi jogsegélyről. HL L 39, 2010. 02. 12., 20-35.

12 Megállapodás az Európai Unió és az Amerikai Egyesült Államok közötti kölcsönös jogsegélyröl. HL L 181, 2003. 07. 19., 34-42. (Még nem lépett hatályba.) Lásd VerVAele, John A. E.: European Criminal Justice in the post-Lisbon Area of Freedom, Security and Justice. Quaderni della Facoltà di Giurisprudenza; 5. Università degli studi di Trento, Trento, 2014, 157.

13 Dánia és Írország nem vett részt az ENYH irányelv elfogadásában, rájuk nézve az nem kötelező és nem alkalmazandó. Lásd ENYH irányelv (44)-(45) preambulumbekezdések.

14 Európai Bizottság - Tájékoztató. Brüsszel, 2018. január 25. http://europa.eu/rapid/press-release_MEMO18-349_hu.htm (2018. 11. 12.).

15 https://www.ejn-crimjust.europa.eu/ejn/EJN_Library_StatusOflmpByCat.aspx?Categoryld=120 (2018. 11. 12.). 


\section{Az európai nyomozási határozatról szóló irányelv implementálása Magyarországon}

Magyarország a 2017. május 23. napjától hatályos, az európai uniós és a nemzetközi bünügyi együttmüködést szabályozó törvények és ehhez kapcsolódóan más törvények jogharmonizációs célú módosításáról szóló 2017. évi XXXIX. törvénnyel tett eleget az irányelv átültetésére irányuló kötelezettségének, amely módosította többek között az európai nyomozási határozat vonatkozásában a szabálysértési jogsegélyröl szóló 2007. évi XXXVI. törvényt, illetve az Európai Unió tagállamaival folytatott bünügyi együttmüködésröl szóló 2012. évi CLXXX. törvényt (a továbbiakban: Ebem. tv.) is. Az alábbiakban bemutatom, hogy ez utóbbi jogszabályba - tehát kifejezetten a büntetőügyekben folytatott együttmüködés vonatkozásában - az irányelvben szereplő előírások hogyan kerültek beillesztésre. ${ }^{16}$

\subsection{Az ENYH célja}

1. táblázat. Az ENYH célja

\begin{tabular}{|c|c|}
\hline Az ENYH irányelv tartalma & Az Ebem. tv. vonatkozó rendelkezései \\
\hline $\begin{array}{l}\text { Az 1. cikk (1) bekezdés alapján egy vagy több } \\
\text { konkrét nyomozási cselekmény bizonyíték- } \\
\text { szerzés céljából történő végrehajtása. }\end{array}$ & $\begin{array}{l}\text { A 36. § alapján: } \\
\text { - bizonyíték megszerzése céljából egy vagy } \\
\text { több eljárási cselekmény végrehajtása, illet- } \\
\text { ve } \\
\text { - a végrehajtó tagállam illetékes hatósága } \\
\text { számára már rendelkezésre álló bizonyitási } \\
\text { eszköz átadása. } \\
\text { Az } 53 \text {. § alapján: } \\
\text { - bármely, a Be. }{ }^{17} \text { szerinti, bizonyitási eszköz } \\
\text { beszerzésére alkalmas eljárási cselekmény } \\
\text { elvégzése. }\end{array}$ \\
\hline
\end{tabular}

Amennyiben az ENYH kibocsátásának célját vizsgáljuk az ENYH irányelv tartalma és az Ebem. tv. rendelkezései alapján, könnyen észlelhetö, hogy míg az irányelvben nyomozási cselekménye ${ }^{18}$ elvégzése szerepel célként, addig ez az Ebem. tv.-be egy sokkal szélesebb jelentéstartalommal bíró, „eljárási cselekmény végrehajtása" terminológia alkalmazásával került átültetésre. Emellett nem találunk egyértelmű rendelkezést arra vonatkozóan sem - az ENYH elnevezésétöl eltekintve -, hogy egy olyan jogintézményröl lenne szó, amely kizárólag a büntetőeljárás

16 Az ENYH irányelv hatálya nem pusztán a büntetőeljárásokra terjed ki, hanem a szabálysértési eljárásokra is (ENYH irányelv 4. cikk). Jelen tanulmány keretében tehát nem kerül sor a szabálysértési jogsegélyről szóló 2007. évi XXXVI. törvény rendelkezéseinek a vizsgálatára.

17 A büntetőeljárásról szóló 2017. évi XC. törvény (a továbbiakban: Be.).

18 Megjegyzendő, hogy az ENYH irányelv mellőzi a nyomozási cselekmény fogalmának a meghatározását, amelyre Karsai Krisztina már az irányelvtervezethez kapcsolódó tanulmányában is felhívta a figyelmet. KARSAI Krisztina: Emberi jogok védelme és az európai nyomozási határozat. Rendészet és emberi jogok, 2012/3, 27. 
nyomozási szakaszához kapcsolódna. Ha az eljárási cselekmény végrehajtásának a célját vizsgáljuk (amennyiben Magyarország a végrehajtó tagállam: bizonyíték megszerzése, rendelkezésre álló bizonyítási eszköz átadása; amennyiben Magyarország a kibocsátó tagállam: bizonyítási eszköz beszerzése), érzékelhető, hogy a nyomozási szakasz vonatkozásában van a legmeghatározóbb szerepe. Meg kell jegyezni ugyanakkor, hogy a következetesség követelményére való tekintettel is, sokkal indokoltabb lenne az Ebem. tv. 36. §-ban is a bizonyíték helyett a bizonyítási eszköz megszerzése szóhasználat alkalmazása. Mindezek mellett a jogszabály, illetve a mellékletét képező ENYH formanyomtatvány szóhasználata sem egységes, bár érthető módon ez utóbbi átalakítására - nemzeti sajátosságokhoz való igazítására - nem is kerülhetett volna sor.

\subsection{Az ENYH kibocsátására jogosult hatóság}

2. táblázat. Az ENYH kibocsátására jogosult hatóság

\begin{tabular}{|c|c|}
\hline Az ENYH irányelv tartalma & Az Ebem. tv. vonatkozó rendelkezései \\
\hline $\begin{array}{l}\text { A 2. cikk alapján: } \\
\text { - az ügyben hatáskörrel rendelkező bíró, bí- } \\
\text { róság, nyomozási bíró vagy ügyész, vagy } \\
\text { - bármely más, a kibocsátó állam által meg- } \\
\text { határozott és az adott ügyben a büntetöeljá- } \\
\text { rás során nyomozó hatóságként eljáró ille- } \\
\text { tékes hatóság, amely a nemzeti jog szerint } \\
\text { hatáskörrel rendelkezik a bizonyítékgyüjtés } \\
\text { elrendelésére, és amely minden egyes } \\
\text { esetben érvényesíttette valamely igazság- } \\
\text { ügyi hatósággal az adott ENYH-t. }\end{array}$ & $\begin{array}{l}\text { Amennyiben Magyarország a végrehajtó tagál- } \\
\text { lam, a } 36 \text {. § alapján: } \\
\text { - igazságügyi hatóság vagy } \\
\text { - más hatóság, azonban ez utóbbi esetben } \\
\text { igazságügyi hatóság általi jóváhagyás szük- } \\
\text { séges. } \\
\text { Amennyiben Magyarország a kibocsátó tagál- } \\
\text { lam, az } 53 \text {. § alapján: } \\
\text { - hivatalból, illetve a terhelt vagy a védő in- } \\
\text { dítványára az a bíróság vagy ügyészség, } \\
\text { amely előtt a büntetőeljárás folyamatban } \\
\text { van } \\
\text { - ha az eljárási cselekmény elrendelésére a } \\
\text { nyomozási bíró jogosult, az elrendelésről az } \\
\text { ügyészség indítványára dönt. }\end{array}$ \\
\hline
\end{tabular}

Az egyes tagállamok között vannak eltérések - az irányelv szabta keretek között - a tekintetben, hogy mely hatóság jogosult a büntetöügyekben alkalmazott nyomozási határozatok kibocsátására. Tekintettel azonban arra, hogy maga az irányelv az ENYH-t egy olyan bírósági határozatként aposztrofálja, amelyet valamely tagállam igazságügyi hatósága ad ki vagy érvényesít, s e körben a nyomozó hatóságokat is nevesíti, amennyiben annak határozatát igazságügyi hatóság érvényesítette, így az alapvető különbség abban keresendő, hogy a tagállamok nemzeti jogában megjelölésre kerülnek-e a nyomozó hatóságok vagy más hatóságok is mint kibocsátó hatóságok. Számos tagállam, például Horvátország, Észtország, Franciaország, Olaszország, Lettország, Litvánia, Hollandia, Portugália, Románia, Szlovákia, 
Svédország ${ }^{19}$ azt a megoldást választotta az implementáció során - ahogyan az a jogalkotók prekoncepciója is volt e tekintetben -, hogy az ENYH kibocsátására kizárólag az ügyben hatáskörrel rendelkező bíró, bíróság, nyomozási bíró vagy ügyész jogosult. ${ }^{20}$ Ezt erősíti a magyar megoldás is, hiszen az Ebem. tv.-ben is kibocsátó hatóságként kizárólag az ügyészség vagy a bíróság kerül megjelölésre, azonban amennyiben Magyarország a végrehajtó tagállam, úgy külön nevesíti az egyéb hatóságok körét is.

\subsection{Az ENYH kibocsátásának feltételei}

3. táblázat. Az ENYH kibocsátásának feltételei

\begin{tabular}{|c|c|}
\hline Az ENYH irányelv tartalma & Az Ebem. tv. vonatkozó rendelkezései \\
\hline $\begin{array}{l}\text { 6. cikk: } \\
\text { - a szükségesség és arányosság kritériumá- } \\
\text { nak érvényesülése mellett, továbbá a bün- } \\
\text { tetőeljárás alá vont személy jogaira figye- } \\
\text { lemmel kerülhet sor a kibocsátására, továbbá } \\
\text { - a megjelölt nyomozási cselekmények ugyan- } \\
\text { ezen feltételek mellett egy hasonló belföldi } \\
\text { ügyben is elrendelhetők lennének. }\end{array}$ & $\begin{array}{l}\text { 53. §: ha az a büntetöeljárásban szükséges és } \\
\text { arányos, }{ }^{21} \text { illetve az adott eljárási cselekmény } \\
\text { az ENYH-ban leírt feltételekkel a magyar jog- } \\
\text { szabályok szerint is elvégezhető lenne. }\end{array}$ \\
\hline
\end{tabular}

Az ENYH kibocsátásának feltételeként pusztán az írható elö, hogy egyrészt feleljen meg a szükségesség-arányosság, másrészt pedig a jogszerüség követelményének. Tehát hasonló belföldi ügyben is elrendelhető legyen az adott eljárási cselekmény. ${ }^{22}$

19 Az 2017. december 15. napján kelt dokumentum alapján, amelyben Máltára vonatkozóan nem szerepel információ. https://www.ejn-crimjust.europa.eu/ejn/EJN_Library_StatusOflmpByCat.aspx?Categoryld=120 (2018. 11. 12.).

20 Javaslat - Az Európai Parlament és a Tanács irányelve az európai bünügyi nyomozati parancsról. Indokolás, Brüsszel, 2010. június 3. 9288/10 ADD 1. 2. cikk.

21 Az Ebem. tv. indokolása alapján a szükségesség és arányosság követelménye egzakt módon nem határozható meg, hanem csakis az adott ügy körülményeit tekintve mérlegelhető, s kiterjed a költséghatékonyság szempontjának figyelembevételére is. Lásd továbbá KARSAI (2012): i. m., 26.

22 RafARACl, Tommaso: General Considerations on the European Investigation Order. In: Ruggeri (ed.): i. m., 39. 


\subsection{Az ENYH fogadására jogosult hatóság}

4. táblázat. Az ENYH fogadására jogosult hatóság

\begin{tabular}{|c|c|}
\hline Az ENYH irányelv tartalma & Az Ebem. tv. vonatkozó rendelkezései \\
\hline $\begin{array}{l}\text { A 7. cikk (1)-(4) bekezdések alapján: } \\
\text { - Az ENYH-t a kibocsátó hatóság az írásbeli } \\
\text { dokumentálást lehetővé tevő bármely úton } \\
\text { továbbítja a végrehajtó hatóságnak olyan } \\
\text { módon, amely lehetővé teszi a végrehajtó } \\
\text { állam számára a hitelesség megállapítását; } \\
\text { - } \text { hivatalos kommunikációra közvetlenül a ki- } \\
\text { bocsátó hatóság és a végrehajtó hatóság } \\
\text { között kerül sor; } \\
\text { - minden tagállam kijelölhet egy vagy több } \\
\text { központi hatóságot, amelyet megbízhat az } \\
\text { ENYH adminisztratív továbbításával és át- } \\
\text { vételével, továbbá az ENYH-val kapcsola- } \\
\text { tos minden egyéb hivatalos levelezéssel; } \\
\text { - az ENYH az Európai Igazságügyi Hálózat táv- } \\
\text { közlési rendszerén keresztül is továbbítható. } \\
\text { (13) Preambulumbekezdés alapján: } \\
\text { - továbbítási módként igénybe vehető pél- } \\
\text { dául az Európai Bírósági Hálózat vagy az } \\
\text { Eurojust biztonságos távközlési rendszere, } \\
\text { az igazságügyi és bűnüldöző hatóságok ál- } \\
\text { tal használt más csatorna. }\end{array}$ & $\begin{array}{l}\text { A 38. § alapján: } \\
\text { - az ENYH közvetlenül a magyar igazságügyi } \\
\text { hatóság részére továbbítható; } \\
\text { - a tagállami és a magyar igazságügyi ható- } \\
\text { ság a kapcsolatot közvetlenül tartja; } \\
\text { - a tagállami hatóság az ENYH-t az Európai } \\
\text { Igazságügyi Hálózat vagy az Eurojust biz- } \\
\text { tonságos távközlési rendszerén keresztül is } \\
\text { továbbíthatja. }\end{array}$ \\
\hline $\begin{array}{l}\text { 7. cikk (3) bekezdés alapján: } \\
\text { Központi hatóság kijelölésének a lehetőségét } \\
\text { teremti meg. }\end{array}$ & Nem kerül sor központi hatóság kijelölésére. \\
\hline
\end{tabular}

Az ENYH keretében - hasonlóan más kölcsönös elismerés elvén alapuló jogintézményhez - a tagállamok hatóságai közötti vertikális együttmüködésről van szó, amely mellett központi hatóság beiktatására is lehetőséget teremt az irányelv. Mindezek mellett a biztonságos továbbítás érdekében a kibocsátó hatóság további módszereket is igénybe vehet annak biztosítására, hogy az ENYH eljusson a végrehajtó állam illetékes hatóságához. ${ }^{23}$

23 ENYH irányelv (13) preambulumbekezdés. 


\subsection{Végrehajtó hatóság}

5. táblázat. Végrehajtó hatóság

\section{Az ENYH irányelv tartalma}

2. cikk alapján:

- az a hatóság, amely az ENYH elismerésére és végrehajtásának biztosítására, valamint a hasonló belföldi esetekben alkalmazandó eljárások lefolytatására hatáskörrel és illetékességgel rendelkezik;

- bírósági engedély lehet szükséges azokban a végrehajtó államokban, amelyeknek nemzeti joga ezt elöírja.
Az Ebem. tv. vonatkozó rendelkezései

A 37. § alapján:

- járásbíróság;

- ügyészség;

- késedelmet nem türő esetben a megjelölt eljárási cselekmény elvégzésére a hatáskörrel vagy illetékességgel nem rendelkező bíróság vagy ügyészség is jogosult.

Az irányelv értelmében tehát pusztán az a hatóság jelölhető meg végrehajtó hatóságként, amely hasonló belföldi ügyben jogosult is lenne az adott eljárási cselekmény lefolytatására. A tagállamok a kibocsátó hatóság meghatározásához hasonlóan eltérő gyakorlatot követnek a tekintetben, hogy a végrehajtó hatóságok körében megjelölnek-e további hatóságokat a bíróságok, valamint az ügyészségek mellett (pl.: a vonatkozó finn jogszabályban a nyomozó hatóságokat és vámhatóságokat is feltüntetik végrehajtó hatóságként). ${ }^{24}$

\subsection{Az ENYH formai és tartalmi kritériumai}

6. táblázat. Az ENYH formai és tartalmi kritériumai

\begin{tabular}{|c|c|}
\hline Az ENYH irányelv tartalma & Az Ebem. tv. vonatkozó rendelkezései \\
\hline \multicolumn{2}{|c|}{ Elfogadott nyelvek } \\
\hline $\begin{array}{l}\text { 5. cikk (2) bekezdés alapján: } \\
\text { Minden tagállamnak a hivatalos nyelve mellett } \\
\text { meg kell jelölnie azokat a nyelveket, amelye- } \\
\text { ken részére az ENYH továbbítható. }\end{array}$ & $\begin{array}{l}\text { 38. } \S(1) \text { bekezdés alapján: } \\
\text { magyar, angol, francia, német }\end{array}$ \\
\hline \multicolumn{2}{|c|}{ Az ENYH tartalma és formája } \\
\hline $\begin{array}{l}\text { Az 5. cikk (1) bekezdés alapján: } \\
\text { Az irányelv mellékletét képező formanyomtat- } \\
\text { vány alkalmazásáról rendelkezik, valamint a } \\
\text { szükséges tartalmi elemekröl. } \\
\text { A) melléklet: Európai nyomozási határozat } \\
\text { (ENYH) } \\
\text { B) melléklet: Igazolás európai nyomozási hatá- } \\
\text { rozat (ENYH) átvételéről } \\
\text { C) melléklet: Értesítés } \\
\text { A tagállamok arról való értesítésére szolgál, } \\
\text { hogy a területükön technikai segítségük igény- } \\
\text { bevétele nélkül titkos távközlési információgyüj- } \\
\text { tést fognak végezni, végeznek vagy végeztek. }\end{array}$ & $\begin{array}{l}\text { A 38. } \S(1) \text { bekezdés és az } 54 \text {. } \S(1) \text { bekezdés } \\
\text { alapján: } \\
\text { A jogszabály mellékletét képező formanyom- } \\
\text { tatvány alkalmazásáról rendelkezik. } \\
\text { 18. számú melléklet: Európai nyomozási hatá- } \\
\text { rozat (ENYH) } \\
\text { 19. számú melléklet: Igazolás európai nyomo- } \\
\text { zási határozat (ENYH) átvételéröl } \\
\text { 20. számú melléklet: Értesítés } \\
\text { A tagállamok arról való értesítésére szolgál, } \\
\text { hogy a területükön technikai segítségük igény- } \\
\text { bevétele nélkül titkos távközlési információgyüj- } \\
\text { tést fognak végezni, végeznek vagy végeztek. }\end{array}$ \\
\hline
\end{tabular}

24 https://www.ejn-crimjust.europa.eu/ejn/EJN_Library_StatusOflmpByCat.aspx?Categoryld=120 (2018. 11. 12.). 
Az ENYH kibocsátására formalizált eljárás keretében, az Ebem. tv. rendelkezése alapján is az erre rendszeresített formanyomtatvány(ok) alkalmazásával kerül sor, amely(ek) tartalma teljes mértékben egyezik az irányelv mellékletében szereplővel/ szereplőkkel. Lényegében tehát az ENYH maga az „alaphatározat” és a jogsegélykérelem is egyben, mellőzve azt a - más jogintézményekhez kapcsolódó - gyakorlatot, amely az együttmüködés alapjának a határozat alapján kiállított formanyomtatványt tekintette. ${ }^{25}$

\subsection{Az ENYH alapján végrehajtható eljárási cselekmények/az ENYH alkalmazási köre}

7. táblázat. Az ENYH alapján végrehajtható eljárási cselekmények/ az ENYH alkalmazási köre

\begin{tabular}{|c|c|}
\hline Az ENYH irányelv tartalma & Az Ebem. tv. vonatkozó rendelkezései \\
\hline $\begin{array}{l}\text { A 3. cikk alapján: } \\
\text { - valamennyi nyomozási cselekmény; } \\
\text { - kivéve: közös nyomozó csoport létrehozása } \\
\text { és a bizonyítékok közös nyomozó csopor- } \\
\text { ton belüli összegyűjtése. }\end{array}$ & $\begin{array}{l}\text { A 46. § (1) bekezdés alapján: } \\
\text { - bármely, a Be. alapján végrehajtható, bizo- } \\
\text { nyítási eszköz beszerzésére alkalmas eljá- } \\
\text { rási cselekmény; } \\
\text { - feltéve: az adott büncselekmény miatt a ma- } \\
\text { gyar büntetőeljárásban is sor kerülhetne az } \\
\text { alkalmazására; } \\
\text { - kivétel: közös nyomozó csoportok létreho- } \\
\text { zása és bizonyíték közös nyomozó csopor- } \\
\text { ton belüli megszerzése. }\end{array}$ \\
\hline
\end{tabular}

Az ENYH megalkotásának alapvető funkciója volt mindazon jogintézmények felváltása, amelyek valamilyen bizonyíték megszerzésére irányultak egy másik tagállamban a büntetőeljárás során. Ezek eljárási rendszerét kívánta egységesíteni és egyszerűsíteni. Ebből a célkitűzésből eredően is, ratione materiae hatálya minden nyomozási cselekményre kiterjed, kivéve a közös nyomozó csoport létrehozására, illetve a bizonyítékok közös nyomozó csoporton belüli összegyűjtésére, amelynek alapját továbbra is az Európai Unió tagállamai közötti kölcsönös bünügyi jogsegélyről szóló egyezmény 13. cikke és a közös nyomozó csoportokról szóló 2002/465/IB kerethatározat ${ }^{26}$ képezi. ${ }^{27}$ Mindehhez képest érdemes megvizsgálni az Ebem. tv.ben alkalmazott megoldást, amely első olvasásra talán azt a benyomást keltheti, hogy az ENYH hatálya korlátozásra került az átültetés során, azonban ha figyelembe vesszük az irányelv további rendelkezéseit, akkor jól látható, hogy pusztán pontosításról van szó. Így azon feltétel, amely szerint kizárólag a Be. alapján végrehajtható,

25 Az Ebem. tv. javaslatához füzött miniszteri indokolás.

26 A Tanács kerethatározata (2002. június 13.) a közös nyomozó csoportokról. 2002/465/IB. HL L 162, 2002. 06. 20., 1-3.

27 A közös nyomozó csoport keretében megszerzett bizonyíték a csoporton belül átadható, a tagok között már nem merül fel az ENYH kibocsátásának szükségessége. Lásd Javaslat - Az Európai Parlament és a Tanács irányelve az európai bủnügyi nyomozati parancsról. Indokolás. Brüsszel, 2010. június 3. 9288/10 ADD 1. 3. cikk. TöRö Andrea: Gondolatok az Európai nyomozási határozat szabályozásáról és gyakorlati alkalmazásáról. Ügyészségi Szemle, 2017/4, 11-12. 
bizonyítási eszköz beszerzésére alkalmas eljárási cselekményről lehet szó, levezethető az ENYH céljából, miszerint az bizonyíték megszerzésére irányulhat, másrészt a kibocsátás feltételeiből, amely alapján az adott eljárási cselekmény, meghatározott feltételekkel az érintett tagállam nemzeti joga alapján is elvégezhető lenne. ${ }^{28}$

\subsection{Eljárási határidők az ENYH alkalmazása során}

8. táblázat. Eljárási határidők az ENYH alkalmazása során

\begin{tabular}{|c|c|}
\hline Az ENYH irányelv tartalma & Az Ebem. tv. vonatkozó rendelkezései \\
\hline \multicolumn{2}{|c|}{ Elismerésre vonatkozó határidők } \\
\hline $\begin{array}{l}\text { A 12. cikk (1), (3) és (5) bekezdések alapján: } \\
\text { - az elismeréssel vagy végrehajtással kap- } \\
\text { csolatos határozatot ugyanolyan gyorsan } \\
\text { és ugyanolyan elsőbbséggel kell meghozni, } \\
\text { mint egy hasonló belföldi ügyben; } \\
\text { - az ENYH elismerésére vagy végrehajtásá- } \\
\text { ra vonatkozó döntést a lehetö legrövidebb } \\
\text { időn belül, de legkésőbb az ENYH-nak az } \\
\text { illetékes végrehajtó hatóság általi átvételét } \\
\text { követő } 30 \text { napon belül meg kell hozni, } \\
\text { - amennyiben ez a határidő nem tartható, leg- } \\
\text { feljebb } 30 \text { nappal meghosszabbítható (közöl- } \\
\text { ni kell a késedelem okát és a döntés megho- } \\
\text { zatalához elöreláthatólag szükséges időt). }\end{array}$ & $\begin{array}{l}\text { A 39. § (1)-(3) bekezdések alapján: } \\
\text { - } \text { haladéktalanul megvizsgálja; } \\
\text { - legkésőbb az ENYH kézhezvételétől számí- } \\
\text { tott } 30 \text { napon belül dönt a végrehajtásról; } \\
\text { - } \text { ha a fenti határidő nem tartható, a kézhez- } \\
\text { vételtől számított } 60 \text { nap áll rendelkezésre } \\
\text { (a késedelem okainak megjelölése is szük- } \\
\text { séges). }\end{array}$ \\
\hline \multicolumn{2}{|c|}{ Végrehajtásra vonatkozó határidők } \\
\hline $\begin{array}{l}\text { 12. cikk (2), (4), (5) és (6) bekezdések: } \\
\text { - ha a kibocsátó hatóság rövidebb határidő } \\
\text { szükségességét jelezte, vagy megjelölte, } \\
\text { hogy a nyomozási cselekményt egy adott } \\
\text { napon kell elvégezni, a kérésre a lehető leg- } \\
\text { nagyobb mértékben tekintettel kell lenni; } \\
\text { - ha ez nem lehetséges, késedelem nélkül } \\
\text { értesítenie kell a kibocsátó állam illetékes } \\
\text { hatóságát és közölni a késedelem okát; } \\
\text { - késedelem nélkül, de legkésöbb a végrehaj- } \\
\text { tásról szóló döntést követő } 90 \text { napon belül } \\
\text { végre kell hajtani a nyomozási cselekményt; } \\
\text { - kivéve: halasztás oka áll fenn vagy a bizonyí- } \\
\text { ték már a végrehajtó állam birtokában van; } \\
\text { - ha a } 90 \text { napos határidő nem tartható, kése- } \\
\text { delem nélkül értesítenie kell a kibocsátó ál- } \\
\text { lam illetékes hatóságát és közölni a késede- } \\
\text { lem okát, valamint konzultációt kell folytatni a } \\
\text { nyomozási cselekmény időzítéséről. }\end{array}$ & $\begin{array}{l}\text { 46. § (4) és (5) bekezdések: } \\
\text { - az ENYH végrehajtásáról szóló döntés } \\
\text { meghozatalát követő } 90 \text { nap; } \\
\text { - } \text { kivétel: soron kívüli végrehajtás vagy eljá- } \\
\text { rási cselekmény végrehajtási időpontjának } \\
\text { meghatározása; } \\
\text { - } \text { ha a } 90 \text { napos határidő nem tartható: érte- } \\
\text { sítés, szükséges időtartam meghatározása, } \\
\text { illetve konzultáció folytatása szükséges az } \\
\text { eljárási cselekmény ütemezéséről. }\end{array}$ \\
\hline
\end{tabular}

28 Szükséges azonban figyelemmel lenni az - ENYH irányelv 10 cikkében foglalt, jelen tanulmány 1.9. pontjában tárgyalt - eltérő nyomozási cselekmény foganatosításának a lehetőségére, amely azokban az esetekben merülhet fel, ha az ENYH-ban megjelölt nyomozási cselekmény a végrehajtó állam jogában nem létezik, vagy az ENYH-ban megjelölt nyomozási cselekményt hasonló belföldi ügyben nem lehetne végrehajtani. 
Az eljárási határidők vonatkozásában az Ebem. tv.-ben alkalmazott előírások az irányelv tartalmával - apróbb eltérésektől eltekintve - szinte teljes egyezőséget mutatnak. Ilyen kisebb eltérésként értékelhető az elismerésre előirt határidők tekintetében az az előírás, miszerint a végrehajtó tagállam köteles a kibocsátó hatóságot értesíteni arról, ha az elismerésre előirt határidő nem tartható, s közölni kell a döntés meghozatalához előreláthatólag szükséges időt. Ez utóbbi követelmény azonban az Ebem. tv.-ben nem található meg.

\subsection{Eltérő eljárási cselekmény foganatosítása}

9. táblázat. Eltérő eljárási cselekmény foganatosítása

\begin{tabular}{|c|c|}
\hline Az ENYH irányelv tartalma & Az Ebem. tv. vonatkozó rendelkezései \\
\hline $\begin{array}{l}\text { 10. cikk (1) és (3) bekezdések: } \\
\text { - az ENYH-ban megjelölt nyomozási cselek- } \\
\text { mény a végrehajtó állam jogában nem léte- } \\
\text { zik, vagy } \\
\text { - hasonló belföldi ügyben nem lehetne végre- } \\
\text { hajtani; } \\
\text { - olyan kisebb beavatkozássaljáró eszköz(ök) } \\
\text { áll(nak) rendelkezésre a végrehajtó állam- } \\
\text { ban, amelyek ugyanazzal az eredménnyel } \\
\text { jár(nak). }\end{array}$ & $\begin{array}{l}\text { 39. § (7) bekezdés: ha rendelkezésre áll olyan } \\
\text { eljárási cselekmény, amely alkalmas az ENYH- } \\
\text { ban megjelölt bizonyíték megszerzésére, } \\
\text { ugyanakkor kisebb jogkorlátozással jár. } \\
\text { 42. § (1) bekezdés: amennyiben az ENYH } \\
\text { végrehajtása megtagadható lenne, ugyanis a } \\
\text { megjelölt eljárási cselekmény a magyar jogban } \\
\text { nem ismert vagy a foganatositásának feltételei } \\
\text { nem állnak fenn, ugyanakkor rendelkezésre } \\
\text { áll olyan további eljárási cselekmény, amely } \\
\text { alkalmas az elérni kívánt bizonyíték megszer- } \\
\text { zésére. }\end{array}$ \\
\hline
\end{tabular}

Az ENYH egyik újítása, hogy a kibocsátó tagállam jogosult meghatározni az elvégzendő nyomozási cselekmény típusát, azonban az eltérő nyomozási cselekmény foganatosításának lehetőségével ehhez kellő rugalmasságot is biztosít.. ${ }^{29}$ Az az esetkör ugyanis, amikor az adott nyomozási cselekmény a végrehajtó tagállamban nem ismert vagy hasonló belföldi ügyben azt nem lehetne végrehajtani, az ENYH megtagadását eredményezné.

29 Például az ENYH olyan bűncselekmény vonatkozásában irányulna bírói engedélyhez kötött leplezett eszköz alkalmazására, amelyre a Be. alapján nincs lehetőség. Javaslat - Az Európai Parlament és a Tanács irányelve az európai bűnügyi nyomozati parancsról. Indokolás. Brüsszel, 2010. június 3. 9288/10 ADD 1. 9. cikk. További példákat ad KARSAI (2012): i. m., 26. 


\subsection{A végrehajtás során irányadó jog}

10. táblázat. A végrehajtás során irányadó jog

\begin{tabular}{|c|c|}
\hline Az ENYH irányelv tartalma & Az Ebem. tv. vonatkozó rendelkezései \\
\hline $\begin{array}{l}\text { A 9. cikk (1) és (2) bekezdések alapján: } \\
\text { - ugyanúgy és ugyanolyan feltételekkel kell } \\
\text { gondoskodni a végrehajtásról, mintha azt a } \\
\text { végrehajtó állam valamely hatósága rendel- } \\
\text { te volna el; } \\
\text { - be kell tartania a kibocsátó hatóság által } \\
\text { megjelölt alaki követelményeket és eljárá- } \\
\text { sokat, kivéve, ha azok ellentétesek a végre- } \\
\text { hajtó állam alapvető jogelveivel. }\end{array}$ & $\begin{array}{l}\text { A 46. § (2) bekezdés alapján: } \\
\text { - az eljárási cselekmények foganatosítása } \\
\text { során a magyar jog szabályai az irányadók. } \\
\text { A 46. § (3) bekezdés alapján: } \\
\text { - a tagállami hatóság által megjelölt szabá- } \\
\text { lyok és technikai módszerek alkalmazása a } \\
\text { végrehajtás során, feltéve ha az nem ösz- } \\
\text { szeegyeztethetetlen a magyar jogrendszer } \\
\text { alapelveivel. } \\
\text { A 47. § (1) bekezdés alapján: } \\
\text { - az eljárási cselekmény elvégzése során a } \\
\text { bíróság vagy az ügyészség engedélye alap- } \\
\text { ján a kibocsátó tagállam hatóságának a tag- } \\
\text { ja - meghatározott feltételek mellett - jelen } \\
\text { lehet. }\end{array}$ \\
\hline
\end{tabular}

Habár a megszerzett bizonyítási eszközök felhasználhatóságát alapvetően a forum regit actum elv alkalmazása ${ }^{30}$ szolgálná, jelen esetben továbbra is a végrehajtó tagállam joga alapján történő végrehajtás (locus regit actum) az irányadó, amely azonban a kibocsátó hatóság kezdeményezése alapján korlátozható. ${ }^{31}$ A fentiek alapján ugyanis látható, hogy egyértelmű iránymutatást kapnak az érintett hatóságok: míg az ENYH kibocsátása a kibocsátó tagállam nemzeti joga alapján történik, addig az eljárási cselekmények foganatosításakor a végrehajtó tagállam joga a meghatározó a fent megjelölt megszorítások mellett. Az alaki követelmények, eljárások megjelölése különösen azokban az esetekben lehet jelentős, amelyekben azok betartása a megszerzett bizonyítási eszköz felhasználhatóságának a feltételét is jelenti.

30 Az elv alkalmazása a kibocsátó tagállam eljárási szabályainak az alkalmazását jelentené, amely kiküszöbölhetné a végrehajtó tagállamban megszerzett bizonyítási eszközök felhasználhatóságának a megkérdőjelezését. Az ENYH irányelv 9. cikk (1) bekezdésében ugyanakkor az asszimiláció elvének érvényesülése érhető tetten annak a követelménynek a meghatározásával, hogy ugyanúgy és ugyanolyan feltételekkel kell gondoskodni a végrehajtásról, mintha azt a végrehajtó állam valamely hatósága rendelte volna el. Lásd erröl részletesen KARSAI Krisztina: Az alapelvek rendszere az európai büntetőjogban. MTA doktori értekezés, Szeged, 2015, 158-170.

31 RAfARACI: i. m., 42. 


\subsection{A kettős büntethetőség követelményének érvényesülése}

11. táblázat. A kettős büntethetőség követelményének érvényesülése

\begin{tabular}{|c|c|}
\hline Az ENYH irányelv tartalma & Az Ebem. tv. vonatkozó rendelkezései \\
\hline $\begin{array}{l}\text { 11. cikk: } \\
\text { A kettős büntethetőség kritériuma az ENYH el- } \\
\text { ismerésének vagy végrehajtásának megtaga- } \\
\text { dási okai között szerepel: } \\
\text { - ha az adott cselekmény a végrehajtó állam } \\
\text { joga szerint nem minősül büncselekmény- } \\
\text { nek; } \\
\text { - kivételt képeznek az irányelv mellékletében } \\
\text { megjelölt büncselekménytípusok, feltéve, } \\
\text { hogy azok a kibocsátó állam joga szerint sza- } \\
\text { badságvesztéssel vagy szabadságelvonás- } \\
\text { sal járó intézkedéssel büntethetők, amely- } \\
\text { nek felső határa legalább három év. }\end{array}$ & $\begin{array}{l}\text { 40. § (1) bekezdés d) pont és } 41 \text {. §: } \\
\text { - az ENYH végrehajtása megtagadható, ha } \\
\text { az sértené a kettős büntethetőség elvét; } \\
\text { - } \text { kivételt képeznek a jogszabály } 1 \text {. számú } \\
\text { mellékletében meghatározott büncselekmé- } \\
\text { nyek esetében, ha a kibocsátó tagállamban } \\
\text { az adott büncselekmény legalább három } \\
\text { évig terjedő szabadságvesztéssel vagy sza- } \\
\text { badságelvonással járó intézkedéssel bünte- } \\
\text { tendő; } \\
\text { - szintén kivételt képez, ha az adott cselek- } \\
\text { mény a magyar jogszabályok szerint bűn- } \\
\text { cselekménynek, azonban a kibocsátó tagál- } \\
\text { lam joga szerint szabálysértésnek minősül; } \\
\text { - ugyancsak kivételt képez, ha a kibocsátó } \\
\text { tagállam viszonosságot biztosít. }\end{array}$ \\
\hline
\end{tabular}

Habár az ENYH irányelv deklaráltan a kölcsönös elismerés elvén nyugszik, az ENYH elismerésének vagy végrehajtásának megtagadási okai között szerepel a kettős büntethetőség hiánya, kivéve az irányelv mellékletében felsorolt, meghatározott büncselekménytípusok esetében. Azt a kört, amikor a magyar bíróság vagy ügyészség a kettős büntethetőség követelményét nem vizsgálja, az Ebem. tv. az irányelv tartalmához képest két esetkörrel tovább bőviti. Egyrészt azzal, amikor az ENYH alapját képező cselekmény a kibocsátó tagállam joga alapján szabálysértésnek, azonban a magyar jog alapján búncselekménynek minősül. Az irányelv 4. cikke maga deklarálja ugyanis azon eljárástípusok körét, amelyek keretében az ENYH kibocsátható, $s$ idetartoznak - meghatározott feltételek mellett - az egyes bünügyi vonatkozású közigazgatási eljárások is. Szintén nem vizsgálja a magyar bíróság vagy ügyészség a kettős büntethetőség követelményét akkor, amikor viszonosság alapján kell a végrehajtást biztosítani. 


\subsection{Bizonyítási eszközök átadása}

12. táblázat. Bizonyítási eszközök átadása

\begin{tabular}{|c|c|}
\hline Az ENYH irányelv tartalma & Az Ebem. tv. vonatkozó rendelkezései \\
\hline $\begin{array}{l}\text { A 13. cikk alapján: } \\
\text { - indokolatlan késedelem nélkül át kell adni } \\
\text { a végrehajtó állam illetékes hatóságainak } \\
\text { a birtokában lévő, illetve az általa megszer- } \\
\text { zett bizonyítékokat; } \\
\text { - a jogorvoslat elbírálásáig az átadás fel- } \\
\text { függeszthető, kivéve, ha az a nyomozás } \\
\text { megfelelő lefolytatásához, illetve az egyéni } \\
\text { jogok védelme érdekében elengedhetetlen; } \\
\text { - fel kell függeszteni az átadást, ha az súlyos } \\
\text { és helyrehozhatatlan kárt okozna az érintett } \\
\text { személynek; } \\
\text { - jelezni kell, hogy a végrehajtó hatóság kéri-e } \\
\text { a bizonyíték(ok) visszaszolgáltatását; } \\
\text { - ideiglenes átadásra kerülhet sor, ha a bizo- } \\
\text { nyitékokat egyéb eljárásokban is használják. }\end{array}$ & $\begin{array}{l}\text { Ha Magyarországon kerül sor az ENYH végre- } \\
\text { hajtására, a 49. § alapján: } \\
\text { - haladéktalanul vagy a tagállami hatóság ál- } \\
\text { tal megjelölt időpontban kerül sor az átadásra; } \\
\text { - átadás helyett kérhető a rendelkezésre állás- } \\
\text { ról való tájékoztatás; } \\
\text { - az átadás feltételeként szabható, hogy az } \\
\text { átadáskorival azonos állapotban szolgáltas- } \\
\text { sák vissza; } \\
\text { - a bizonyítási eszköz átadása elhalasztható, } \\
\text { ha az más büncselekmény felderítéséhez, } \\
\text { bizonyitásához szükséges, illetve az ENYH } \\
\text { végrehajtása során hozott határozat vagy } \\
\text { intézkedés ellen jogorvoslattal éltek; } \\
\text { - az átadást a jogorvoslat elbírálásáig el kell } \\
\text { halasztani, ha az érintett személynek súlyos } \\
\text { hátrányt okozna az átadás; } \\
\text { - a bizonyítási eszköz meghatározott időtar- } \\
\text { tamra ideiglenesen is átadható. } \\
\text { Ha Magyarországon kerül sor az ENYH kibo- } \\
\text { csátására, az } 57 \text {. § alapján: } \\
\text { - az átvételre az ENYH-t kibocsátó bíróság, } \\
\text { ügyészség vagy ezek megbízása alapján a } \\
\text { nyomozó hatóság jogosult; } \\
\text { - ha az eljáró hatóság tagja a tagállam terüle- } \\
\text { tén jelen van, közvetlenül átveheti; } \\
\text { - a tagállami hatóság kérheti az átadáskorival } \\
\text { azonos állapotban történő visszaszolgálta- } \\
\text { tást, amennyiben arra már nincs szükség; } \\
\text { - az átadás elhalasztása esetén ideiglenes } \\
\text { átadás kezdeményezhető. }\end{array}$ \\
\hline
\end{tabular}

Az ENYH keretében megszerzett bizonyítékok átadása tekintetében az irányelvben megfogalmazottakhoz képest apróbb eltéréseket mutat az Ebem. tv. Így az átadás alternatívájaként határozza meg, hogy az átadás helyett kérhető a rendelkezésre állásról való tájékoztatás is, amennyiben a kibocsátó hatóság az ENYH-ban azt nem kérte. Emellett pedig míg az irányelv pusztán arra vonatkozóan tartalmaz iránymutatást, hogy az átadott bizonyíték visszaszolgáltatása kérhető, addig az Ebem. tv. már az átadás lehetséges feltételeként határozza meg, hogy a bizonyítási eszközt az átadáskorival azonos állapotban szolgáltassák vissza. Amennyiben az érintett bizonyítási eszközöket és ezzel kapcsolatos iratokat más eljárásban is használják, az irányelv az ideiglenes átadás lehetőségét teremti meg, míg az Ebem. tv. ezt az átadás elhalasztásának egyik okaként nevesíti, bár utóbb - abban az esetben, ha magyar a kibocsátó hatóság - rögzíti, hogy az átadás elhalasztása esetén kérhető a bizonyítási eszköz ideiglenes átadása. 


\subsection{Jogorvoslat}

13. táblázat. Jogorvoslat

\begin{tabular}{|c|c|}
\hline Az ENYH irányelv tartalma & Az Ebem. tv. vonatkozó rendelkezései \\
\hline $\begin{array}{l}\text { 14. cikk: } \\
\text { - a hasonló belföldi esetekben igénybe ve- } \\
\text { hetőkkel egyenértékü jogorvoslatoknak kell } \\
\text { rendelkezésre állni; } \\
\text { - az ENYH kibocsátásának érdemi indokait } \\
\text { csak a kibocsátó államban benyújtott kere- } \\
\text { set útján lehet vitatni, a végrehajtó államban } \\
\text { az alapjogok garanciáinak sérelme nélkül; } \\
\text { - a jogosultak jogorvoslati jogról való tájékoz- } \\
\text { tatás szükségessége, amennyiben az nem } \\
\text { veszélyezteti a titkosság követelményét } \\
\text { (akkor, amikor a jogok igénybe vehetővé } \\
\text { válnak, és kellö időben ahhoz, hogy tényle- } \\
\text { gesen gyakorolni lehessen azokat); } \\
\text { - a jogorvoslat igénybevételére vonatkozó } \\
\text { határidőknek azonosnak kell lenniük a ha- } \\
\text { sonló belföldi esetekben rendelkezésre álló } \\
\text { határidőkkel, oly módon, hogy biztosítsák } \\
\text { azok tényleges igénybevételét; } \\
\text { - jogorvoslati kérelmek bejelentéséről az érin- } \\
\text { tett tagállamok hatóságainak tájékoztatnia } \\
\text { kell egymást; } \\
\text { - a jogorvoslat alapvetően nem függeszti fel } \\
\text { a nyomozási cselekmény végrehajtását, } \\
\text { kivéve, ha hasonló belföldi esetekben ilyen } \\
\text { hatást váltana ki. }\end{array}$ & $\begin{array}{l}\text { Ha Magyarországon kerül sor az ENYH végre- } \\
\text { hajtására, az } 50 \text {. } § \text { alapján: } \\
\text { - a Be. alapján van jogorvoslatnak helye az } \\
\text { ENYH végrehajtása során hozott határozat } \\
\text { vagy intézkedés ellen, amelyben azonban } \\
\text { nem támadható az ENYH-ban meghatáro- } \\
\text { zott eljárási cselekmény elrendelése; } \\
\text { - az adott eljárási cselekmény elrendelése } \\
\text { ellen a kibocsátó tagállam joga szerint van } \\
\text { helye jogorvoslatnak. } \\
\text { Ha Magyarországon kerül sor az ENYH kibo- } \\
\text { csátására, az } 58 \text {. § alapján: } \\
\text { - a Be. Szabályai alapján van helye jogorvos- } \\
\text { latnak az ENYH-ban megjelölt eljárási cse- } \\
\text { lekmény elrendelése ellen; } \\
\text { - a tagállami hatóság tájékoztatása szüksé- } \\
\text { ges a jogorvoslat bejelentéséröl és elbírálá- } \\
\text { sának eredményéről. }\end{array}$ \\
\hline
\end{tabular}

Az Ebem. tv. jól érthetően, logikus rendszerbe foglaltan ülteti át az irányelv tartalmát a jogorvoslat vonatkozásában, egyértelmüen rögzítve azt, hogy az ENYH kibocsátásával szemben a kibocsátó tagállam nemzeti joga alapján van helye jogorvoslatnak, míg a végrehajtás során hozott határozatok, illetve intézkedések a Be. rendelkezései alapján támadhatóak. Érdemes azonban figyelemmel lenni arra, hogy a végrehajtó hatóság döntése nem szükségszerüen igényel határozati formát, csak akkor, ha a Be. alapján az határozati formához kötött. Így az ENYH végrehajtásának megtagadása esetén sem általában kötelező a határozati forma alkalmazása, bár ehhez nyilvánvalóan nem kötődik az érintettek részéről jogorvoslati jogosultság sem. ${ }^{32}$

${ }^{32}$ Az Ebem. tv. javaslat miniszteri indokolása. 


\subsection{Az eljárási cselekmények egyes különleges formái}

14. táblázat. Az eljárási cselekmények egyes különleges formái

\begin{tabular}{|c|c|}
\hline Az ENYH irányelv tartalma & Az Ebem. tv. vonatkozó rendelkezései \\
\hline $\begin{array}{l}\text { - őrizetben levő személyek nyomozási cse- } \\
\text { lekmény foganatosítása érdekében történő } \\
\text { ideiglenes átadása a kibocsátó államnak }\end{array}$ & $\begin{array}{l}\text { - fogva tartott személy ideiglenes átadása az } \\
\text { európai nyomozási határozatot kibocsátó } \\
\text { tagállamba }\end{array}$ \\
\hline $\begin{array}{l}\text { - őrizetben levő személyek nyomozási cse- } \\
\text { lekmény foganatosítása érdekében történő } \\
\text { ideiglenes átadása a végrehajtó államnak }\end{array}$ & $\begin{array}{l}\text { - fogva tartott személy ideiglenes átadása az } \\
\text { európai nyomozási határozatot végrehajtó } \\
\text { tagállamba }\end{array}$ \\
\hline $\begin{array}{l}\text { - meghallgatás videokonferencia vagy egyéb } \\
\text { audiovizuális közvetítőeszköz segítségével }\end{array}$ & - kihallgatás telekommunikációs eszköz útján \\
\hline - telefonkonferencia útján történő meghallgatás & - kihallgatás telekommunikációs eszköz útján \\
\hline $\begin{array}{l}\text { - információk a bankoknál és egyéb pénzinté- } \\
\text { zeteknél vezetett számlákról }\end{array}$ & $\begin{array}{l}\text { - adatszolgáltatás pénzügyi intézmény által } \\
\text { vezetett számláról és számlaforgalmi ada- } \\
\text { tokról }\end{array}$ \\
\hline $\begin{array}{l}\text { - a bizonyítékok valós idejü, folyamatos, il- } \\
\text { letve meghatározott ideig tartó gyűjtésével } \\
\text { járó nyomozási cselekmények }\end{array}$ & - leplezett eszközök alkalmazása \\
\hline - fedett nyomozás & - leplezett eszközök alkalmazása \\
\hline - titkos távközlési információgyűjtés & - leplezett eszközök alkalmazása \\
\hline - ideiglenes intézkedések & - ideiglenes intézkedés \\
\hline
\end{tabular}

A fenti táblázatban egymás mellett szerepelnek azok az eljárási cselekmények, amelyek az irányelv és az Ebem. tv. rendelkezései alapján megfeleltethetők egymásnak céljuk/tartalmuk alapján. 2018. július 1-jétöl, az új Be. hatálybalépésétől kezdődően több eljárási cselekmény módosult. Így a korábban kihallgatás zárt célú távközlő hálózat útján, valamint a kihallgatás távbeszélő-készülék útján jogintézmények helyett a kihallgatás telekommunikációs eszköz útján eljárási cselekmény szerepel, míg a titkos adatszerzés és a titkos információgyűjtés helyett bevezetésre került a leplezett eszközök alkalmazása. Az irányelv 28. cikkében rendezett, a bizonyítékok valós idejü, folyamatos, illetve meghatározott ideig tartó gyűjtésével járó nyomozási cselekmények körében két eljárási cselekményt nevesít, az egyik az „egy vagy több meghatározott számlán keresztül végrehajtott banki vagy más pénzügyi múveletek nyomon követése”, a másik „,a végrehajtó állam területén való ellenörzött szállítás". Az ezekre vonatkozó szabályokat a leplezett eszközök alkalmazása között találjuk a fedett nyomozás és a titkos távközlési információgyüjtés mellett. Látható tehát, hogy az Ebem. tv. több esetben összevonja az eljárási cselekményekre vonatkozó rendelkezéseket a hazai szabályozásra való tekintettel.

Az Ebem. tv. rendelkezéseinek számbavételét lezárva szükséges még megjegyezni, hogy az irányelvben megjelölt titkosság követelménye - amelyre az ENYH végrehajtása során mind a kibocsátó, mind pedig a végrehajtó hatóság köteles tekintettel lenni ${ }^{33}$ - az Ebem. tv.-ben nem kerül külön deklarálásra.

33 ENYH irányelv 14. cikk (3) bekezdés, 19. cikk. 


\section{Előzetes döntéshozatali eljárás az ENYH irányelv értelmezése kapcsán}

Az ENYH-t érintő első előzetes döntéshozatali eljárás jelenleg már folyamatban van az Európai Unió Bírósága előtt. ${ }^{34}$ Egy bolgár bíróság 2017 májusában terjesztette vonatkozó kérdéseit a Bíróság elé, ${ }^{35}$ amelyek az alábbiak voltak:

1. Összeegyeztethető-e a büntetöügyekben kibocsátott európai nyomozási határozatról szóló 2014/41/EU irányelv 14. cikkével az a nemzeti jog és nemzeti ítélkezési gyakorlat, amely szerint sem közvetlenül a bírósági határozattal szemben elöterjesztett jogorvoslat iránti kérelemmel, sem kártérítés iránti különös keresettel nem támadhatók meg a lakás és üzlethelyiségek átkutatását és meghatározott tárgyak lefoglalását, illetve tanú meghallgatásának engedélyezését elrendelő európai nyomozási határozat érdemi indokai? A 14. cikk ugyanis akként rendelkezik, hogy a tagállamoknak az ENYH-ban megjelölt nyomozási cselekmény vonatkozásában a hasonló belföldi esetekben igénybe vehetőkkel egyenértékủ jogorvoslati lehetöséget kell biztosítaniuk. Az ENYH kibocsátásának érdemi indokai ugyanakkor kizárólag a kibocsátó államban vitathatók. Amennyiben azonban az a nyomozás titkosságához füződő érdeket nem sérti, az érintett tagállamok (kibocsátó és végrehajtó) hatóságait intézkedési kötelezettség terheli a tekintetben, hogy az arra jogosultakat kellő időben tájékoztassák a nemzeti jog szerint rendelkezésre álló jogorvoslati lehetőségekről. Amennyiben jogorvoslati kérelem kerül benyújtásra az ENYH kiadása, elismerése vagy végrehajtása ellen, arról az érintett tagállamok hatóságai kötelesek egymást értesíteni. A jogorvoslati kérelem azonban fő szabály szerint nem rendelkezik szuszpenzív hatállyal a nyomozási cselekmény végrehajtására, kivéve, ha az hasonló belföldi esetekben ilyen hatást váltana ki. ${ }^{36}$

2. Az irányelv 14. cikkének (2) bekezdése - miszerint az ENYH kibocsátásának érdemi indokait csak a kibocsátó államban benyújtott kereset útján lehet vitatni, a végrehajtó államban az alapjogok garanciáinak sérelme nélkül - közvetlenül biztosít-e jogot az érintett fél számára arra, hogy megtámadja az európai nyomozási határozatról rendelkező bírósági határozatot, ha a nemzeti jog nem biztosít ilyen eljárási lehetőséget? Ez a kérdés véleményem szerint két módon is értelmezhető. (1) Egyrészt akként, hogy amennyiben a végrehajtó tagállam nemzeti jogában nem deklarálja azt a jogosultságot, hogy a kibocsátás érdemi indokai a kibocsátó tagállamban benyújtott jogorvoslati indítvány alapján vitathatók, akkor ettől függetlenül van-e helye jogorvoslatnak. (2) Másrészt akként, hogy amennyiben a végrehajtó tagállamban az adott eljárási cselekmény elrendelésével szemben nem állna fenn jogorvoslati lehetőség, ettől függetlenül, az irányelvre hivatkozással az eljárási cselekmény elrendelésével szemben lehet-e jogorvoslattal élni.

3. Az irányelv 6. cikke (1) bekezdésének a) pontjával és 1. cikkének (4) bekezdésével összefüggésben értelmezett 14. cikke (2) bekezdésének figyelembevételével a vádlott tekinthetö-e az irányelv 14. cikkének (4) bekezdése szerinti érintett félnek,

34 C-324/17. sz. ügy: A Spetsializiran nakazatelen sad (Bulgária) által 2017. május 31-én benyújtott előzetes döntéshozatal iránti kérelem - Ivan Gavanozov elleni büntetőeljárás. HL C 256, 2017. 08. 07., 16.

35 WAHL, Thomas: First Case on Interpretation of EIO Brought Before CJEU. Eucrim - The European Criminal Law Associations' Forum, 2018/1, 35.

36 ENYH irányelv 14. cikk. 
ha a bizonyítékgyüjtési intézkedés címzettje harmadik személy? Tehát a büntetőeljárás alá vont személy eljárási jogainak biztosítására tekintettel a vádlott rendelkezik-e jogorvoslati jogosultsággal abban az esetben is, ha az ENYH-ban meghatározott bizonyítékgyűjtési intézkedés harmadik személyt érint. Az irányelv ugyanis akként rendelkezik, hogy a jogorvoslati jogosultság az "érintett feleket” illeti meg, ${ }^{37}$ s mellőzi ez utóbbi fogalom meghatározását.

4. Az irányelv 14. cikkének (2) bekezdésével összefüggésben értelmezett (4) bekezdése szerinti érintett személy-e az a személy, aki a kutatással és lefoglalással érintett helyiségekben lakik vagy azokat használja, illetve az a személy, akit tanúként kívánnak meghallgatni? Jól látható, hogy a negyedik kérdés pedig továbbra is az „érintett felek” fogalmi körének a meghatározására irányul. Tehát ebbe a körbe sorolandó-e a kutatással és lefoglalással érintett helyiség lakója, használója, illetve a tanúként kihallgatandó személy?

Érdemes a feltett kérdésekhez kapcsolódóan megvizsgálni azt, hogy a hatályos magyar szabályozás ezek vonatkozásában milyen rendelkezéseket tartalmaz. Az első kérdés nyilvánvalóan arra vár választ, hogy az irányelv azon rendelkezésének, miszerint „az ENYH kibocsátásának érdemi indokait csak a kibocsátó államban benyújtott kereset útján lehet vitatni, a végrehajtó államban az alapjogok garanciáinak sérelme nélkül”, megfelel-e az a tagállami szabályozás, amely kizárja az ENYH kibocsátásának érdemi indokaira irányuló jogorvoslati lehetőséget a végrehajtó államban. Az Ebem. tv. 50. § (1) és (3) bekezdései alapján - amely szintén ezt a megoldást követi -, amennyiben Magyarország a végrehajtó tagállam, úgy az eljárási cselekmény elrendelése jogorvoslattal kizárólag a kibocsátó tagállam joga szerint támadható. Amennyiben pedig az elrendelés ellen jogorvoslattal éltek, azt a magyar hatóság (bíróság, ügyészség) köteles haladéktalanul a kibocsátó hatóság részére továbbítani, s erről a jogorvoslati nyilatkozat előterjesztőjét tájékoztatni. Ha az arra jogosult az ENYH végrehajtása során hozott határozat vagy intézkedés ellen él jogorvoslattal, arról, illetve az elbírálás eredményéről a végrehajtó hatóság tájékoztatja a kibocsátó hatóságot, valamint elbírálásig a bizonyítási eszköz átadása elhalasztható [Ebem. tv. 50. § (2) bekezdés és 49. § (6) bekezdés]. Abban az esetben, ha az ENYH kibocsátására Magyarországon kerül sor, úgy az elrendelés ellen a jogorvoslatnak a Be. szabályai alapján van helye. Ekkor a tagállami hatóság irányában mind a jogorvoslat bejelentése, mind pedig annak elbírálása vonatkozásában tájékoztatási kötelezettség áll fenn (Ebem. tv. 58. §). A második kérdés - ha az első értelmezési módot vesszük alapul - a hazai szabályozás tekintetében véleményem szerint irreleváns, hiszen egyértelmüen rendezi, hogy az elrendelés ellen kizárólag a kibocsátó tagállam joga szerint van helye jogorvoslatnak [Ebem. tv. 50. § (1) bekezdés]. A harmadik, illetve a negyedik kérdés tekintetében (jogorvoslati jogosultak körének meghatározása) álláspontom szerint az egyes érintett tagállamok nemzeti joga az irányadó. Tehát amennyiben a jogorvoslat az elrendelés érdemi okait vitatja, úgy a kibocsátó tagállam joga irányadó, amennyiben pedig a végrehajtás során hozott határozatot vagy intézkedést kifogásolja, úgy a végrehajtó tagállam vonatkozó nemzeti joga a követendő.

37 ENYH irányelv 14. cikk (2) bekezdés. 


\section{Az ENYH kapcsolata további, a kölcsönös elismerés elvén alapuló jogintézményekkel}

\subsection{Az ENYH és az európai bizonyításfelvételi parancs}

Jelen tanulmány bevezető gondolatai között említésre került, hogy már az ENYH irányelv megalkotása elött is létezett olyan, a kölcsönös elismerés elvén alapuló jogi instrumentum, amely ugyancsak a bizonyításfelvételhez és -átadáshoz kapcsolódott. Az európai bizonyításfelvételi parancsot ugyanis - az ENYH-hoz hasonlóan szintén abból a célból hozták létre, hogy a tagállamok között váltsa fel ebben a körben a kölcsönös jogsegély elvén alapuló jogi eszközöket, azonban ez - több okból kifolyólag, de különösen a korlátozott hatályára tekintettel, ${ }^{38}$ valamint arra, hogy a bizonyítékok későbbi átruházása már a kölcsönös jogsegélyre vonatkozó eljárás keretében történhet ${ }^{39}$ - mégsem következett be. ${ }^{40} \mathrm{Az}$ ENYH irányelv az európai bizonyításfelvételi parancsról szóló kerethatározat helyébe lépett, s ez utóbbi hatályon kívül helyezésre került. ${ }^{41}$

\subsection{Az ENYH és az európai elfogatóparancs (EEP)}

Mint az jól ismert, az európai elfogatóparancs az ENYH-hoz hasonlóan a kölcsönös elismerés elvén alapuló jogintézmény, amelynek alapvető funkciója, hogy a keresett személyt büntetőeljárás lefolytatása vagy szabadságvesztés büntetés, továbbá szabadságelvonással járó intézkedés végrehajtása céljából elfogja és átadja. ${ }^{42}$ Érdemes azonban a kibocsátó igazságügyi hatóságoknak az EEP kibocsátása előtt figyelemmel lenni arra, hogy az adott cél elérésére milyen további eszköz áll rendelkezésre. Ugyanis a büntetöügyekben folytatott igazságügyi együttműködés területén számos olyan, a kölcsönös elismerés elvén alapuló intézkedés létezik, amely kiegészíti az EEP-t, vagy esetlegesen sokkal hatékonyabban szolgálja az adott cél elérését. llyennek tekinthető az ENYH (például egy másik tagállamban tartózkodó gyanúsított videokapcsolaton keresztül történő kihallgatása, egy másik tagállamban

38 Nem tartozik a hatálya alá: kihallgatás lefolytatása, vallomás felvétele, vagy meghallgatás lebonyolítása, vizsgálatok lefolytatása emberi testen vagy emberi testből származó anyagok és biometrikus adatok átadása (így: ujjlenyomat, DNS-minta), valós idejü információ, illetve nyilvánosan elérhető elektronikus hírközlési szolgáltatás vagy a nyilvános hírközlő hálózat szolgáltatói által megőrzött hírközlési adatok megszerzése, létező tárgyak, dokumentumok és adatok vizsgálatának lefolytatása. A Tanács 2008/978/IB kerethatározata 4. cikk részletesebben lásd JÁnosı Andrea: Az európai nyomozási határozat előzményei és vívmányai. Publicationes Universitatis Miskolcinensis Series Juridica et Politica, 2015, Tomus 33, 213-223.

39 Gombos Katalin: Bírói jogvédelem az Európai Unióban - Lisszabon után. CompLex, Budapest, $2011,345$.

40 JÁnosı Andrea: A szabad mozgás büntető eljárásjogi aspektusai, különös tekintettel a bizonyítás kérdésére. PhD-értekezés, Miskolc, 2013, 193-198.

41 Az Európai Parlament és a Tanács (EU) 2016/95 rendelete (2016. január 20.) a büntetöügyekben folytatott rendőrségi és igazságügyi együttműködés területén egyes jogi aktusok hatályon kívül helyezéséről. HL L 26, 2016. 02. 02., 9-12, 1. cikk.

42 A Tanács kerethatározata (2002. június 13.) az európai elfogatóparancsról és a tagállamok közötti átadási eljárásokról. HL L 190, 2002. 07. 18., 1-20, 1. cikk (1) bekezdés. 
tartózkodó gyanúsított azon tagállam illetékes hatóságai által történő kihallgatása, vagy a tárgyalási szakaszt megelőző szakaszban szabadságelvonással nem járó felügyeleti intézkedés végrehajtása érdekében a gyanúsított vonatkozásában); a fogvatartottak átszállítása; ${ }^{43}$ a próbára bocsátást elrendelő határozatok és alternatív szankciók átadása; ${ }^{44}$ az igazságügyi felügyeletet elrendelő európai határozat; ${ }^{45}$ a pénzbüntetések végrehajtása ${ }^{46}$ is. ${ }^{47}$

\subsection{A befagyasztást és az elkobzást elrendelő határozatok kölcsönös elismerése és az ENYH}

2020. december 19-től alkalmazandó az Európai Parlament és a Tanács a befagyasztást és az elkobzást elrendelő határozatok kölcsönös elismeréséröl szóló (EU) 2018/1805 rendelete ${ }^{48}$ azon tagállamok vonatkozásában, amelyekre nézve e rendelet kötelező, s felváltja a vagyon befagyasztása tekintetében a 2003/577/IB ${ }^{49}$ és a 2006/783/IB ${ }^{50}$ tanácsi kerethatározatokat, amelyek jelenleg e körben az uniós jogi keretet alkotják. ${ }^{51}$ Érdemes megemlíteni, hogy az ENYH irányelv a bizonyíté-

${ }^{43}$ A Tanács 2008/909/IB kerethatározata (2008. november 27.) a kölcsönös elismerés elvének büntetöügyekben hozott, szabadságvesztés-büntetéseket kiszabó vagy szabadságelvonással járó intézkedéseket alkalmazó ítéleteknek az Európai Unióban való végrehajtása céljából történő alkalmazásáról. HL L 327 , 2008. 12. 05., 27-46.

44 A Tanács 2008/947/IB kerethatározata (2008. november 27.) a kölcsönös elismerés elvének az ítéletekre és próbaidőt megállapító határozatokra való, a próbaidő alatti magatartási szabályok és alternatív szankciók felügyelete céljából történő alkalmazásáról. HL L 337, 2008. 12. 16., 102-122.

45 A Tanács 2009/829/IB kerethatározata (2009. október 23.) a kölcsönös elismerés elvének az Európai Unió tagállamai közötti, az előzetes letartóztatás alternatívájaként felügyeleti intézkedéseket elrendelő határozatokra történő alkalmazásáról. HL L 294, 2009. 11. 11., 20-40.

46 A Tanács 2005/214/IB kerethatározata (2005. február 24.) a kölcsönös elismerés elvének a pénzbüntetésekre való alkalmazásáról. HL L 76, 2005. 03. 22., 16-30.

47 A Bizottság közleménye kézikönyv az Európai elfogatóparancs kibocsátásáról és végrehajtásáról. HL C 335, 2017. 10. 06., 1-83.

2.5. A büntetőügyekben folytatott igazságügyi együttmüködés terén létező uniós jogi eszközök alapján rendelkezésre álló más intézkedések.

48 Az Európai Parlament és a Tanács (EU) 2018/1805 rendelete (2018. november 14.) a befagyasztást és az elkobzást elrendelő határozatok kölcsönös elismeréséröl. HL L 303, 2018. 11. 28., 1-38.

49 A Tanács 2003/577/IB kerethatározata (2003. július 22.) a vagyonnal vagy bizonyitékkal kapcsolatos biztosítási intézkedést elrendelő határozatoknak az Európai Unióban történő végrehajtásáról. HL L 196, 2003. 08. 02., 45-55.

50 A Tanács 2006/783/IB kerethatározata (2006. október 6.) a kölcsönös elismerés elvének a vagyonelkobzást elrendelő határozatokra történő alkalmazásáról. HL L 328, 2006. 11. 24., 59-78.

51 A 2003/577/IB kerethatározat célja, hogy olyan jogi keretrendszert alkosson, amelyek alapján egy tagállam elismeri és saját területén végrehajtja egy másik tagállam igazságügyi hatósága által büntetőeljárás során kibocsátott, biztosítási intézkedést elrendelő határozatokat. llyen határozatnak minősül: elkobzás alá vonható vagyon vagy bizonyíték megsemmisítésére, átalakítására, elvitelére, átruházására, elidegenítésére irányuló cselekmény ideiglenes megakadályozása érdekében a kibocsátó állam igazságügyi hatósága által hozott bármely intézkedés. (Lásd 2003/577/IB kerethatározat 1. és 2. cikkek.) A 2006/783/IB kerethatározat célja, hogy olyan jogi keretrendszert alkosson, amely alapján egy tagállam elismeri és saját területén végrehajtja az egy másik tagállam büntetöügyekben illetékes bírósága által hozott vagyonelkobzást elrendelő határozatokat. Vagyonelkobzást elrendelő határozatnak minősül az olyan bűncselekménnyel vagy bűncse- 
kok biztosítása tekintetében - azon tagállamok vonatkozásában, amelyekre nézve az irányelv kötelező - már felváltotta a 2003/577/IB kerethatározat rendelkezéseit. Ebbe a körbe sorolandók a bizonyítékként felhasználható elemek megsemmisítésének, átalakításának, áthelyezésének, átadásának vagy elidegenítésének ideiglenes megakadályozását szolgáló ideiglenes intézkedések. ${ }^{52}$ Ugyanakkor meg kell jegyezni, hogy az ENYH irányelv alapvetően a bizonyítékgyűjtés célját szolgáló ideiglenes intézkedésekkel foglalkozik, azonban a pénzügyi eszközökre is kiterjedhet. ${ }^{53}$ Mindezek mellett a 2003/577/IB kerethatározatnak a vagyon befagyasztásával kapcsolatos rendelkezései, továbbá a 2006/783/IB kerethatározat rendelkezései továbbra is alkalmazandók azon tagállamok között, amelyekre nézve a 2018/1805 rendelet nem kötelező, illetve az olyan tagállamok között is, amelyek közül ugyan az egyikre nézve kötelező, azonban a másikra nem. ${ }^{54}$

\subsection{Elektronikus bizonyítékok beszerzése és az ENYH}

A Bizottság 2018. április 17-én fogadta el a büntetőügybeli elektronikus bizonyítékokra vonatkozó, közlésre és megőrzésre kötelező európai határozatokról szóló rendelet javaslatát, ${ }^{55}$ amelynek alapvető célkitüzése, hogy elektronikus bizonyítékok beszerzésére irányuló alternatív megoldást vezessen be a nemzetközi együttmüködés és a kölcsönös jogsegély jelenleg rendelkezésre álló eszközei mellett. ${ }^{56}$ Célja egy olyan kölcsönös elismerés elvén alapuló jogi instrumentum kidolgozása, amely lehetővé teszi a más joghatósági területen található elektronikus bizonyítékok beszerzését vagy megőrzésre kötelezését az adott joghatóság illetékes hatóságainak bevonása nélkül. ${ }^{57}$ Tehát lényegében lehetőséget teremtene arra, hogy egy tagállam igazságügyi hatósága közvetlenül határozatot intézzen egy másik tagállamban letelepedett szolgáltatóhoz, illetve annak jogi képviselőjéhez, s tőle elektronikus bizonyítékok rendelkezésre bocsátását kérje. Annak a tagállamnak az igazságügyi hatósága pedig, ahol a szolgáltató vagy annak képviselője található, kizárólag abban az esetben kapcsolódna be az eljárásba, ha a szolgáltató a megkeresésnek nem tenne eleget.

Természetesen ezt a megoldást több tekintetben is aggályosnak találták a rendelettervezetet véleményező szakértő csoportok, és egy értesítési mechanizmus beiktatására tettek javaslatot, amely két irányban is megvalósulhatna. Egyrészt a

lekményekkel kapcsolatos eljárás eredményeként, bíróság által hozott jogerős szankció vagy intézkedés, amely végleges tulajdonvesztést eredményez. (Lásd 2006/783/IB kerethatározat 1. és 2. cikkek.)

52 ENYH irányelv 32. cikk.

53 ENYH irányelv (34) preambulumbekezdés.

54 Az Európai Parlament és a Tanács (EU) 2018/1805 rendelete (52) preambulumbekezdés.

55 Javaslat az Európai Parlament és a Tanács rendelete a büntetöügybeli elektronikus bizonyítékokra vonatkozó, közlésre és megőrzésre kötelező európai határozatokról. COM/2018/225 final.

56 Javaslat - Az Európai Parlament és a Tanács rendelete a büntetőügybeli elektronikus bizonyítékokra vonatkozó, közlésre és megőrzésre kötelező európai határozatokról - Irányadó vita. Brüsszel, 2018. október 4.

57 Az Európai Parlament és a Tanács rendelete a büntetőügybeli elektronikus bizonyítékokra vonatkozó, közlésre és megőrzésre kötelező európai határozatokról - Általános megközelítés. Brüsszel, 2018. november 30. 
szolgáltató vagy annak jogi képviselője szerinti tagállam értesítésével, amely alapján az értesített tagállam igazságügyi hatósága konzultációt kezdeményezhetne a kibocsátó hatósággal, vagy jogosultsággal rendelkezne arra, hogy a határozat jogszerüségét megvizsgálja, illetve a határozat végrehajtását esetlegesen megtagadja. Másrészt azon személy szerinti tagállam értesítésével, amelynek az adatai átadását kérik. ${ }^{58}$ Érdemes ugyanakkor megvizsgálni a közlésre kötelező európai határozat és a megőrzésre kötelező európai határozat kapcsolatát az ENYH-val, amely ugyancsak lehetőséget teremt az elektronikus bizonyítékok beszerzésére, azonban nem tartalmaz speciális rendelkezéseket ezek vonatkozásában. Pusztán az ENYH irányelv 10. cikk (2) bekezdés e) pontjában található rendelkezés az adott telefonszámhoz vagy IP-címhez tartozó előfizetéssel rendelkező személyek azonosítására irányuló nyomozási cselekményekre vonatkozik, amely azon nyomozási cselekmények körébe sorolandó, amelyeknek minden esetben rendelkezésre kell állniuk a végrehajtó állam joga szerint. Tehát nem áll rendelkezésre az a megoldás, hogy - bizonyos feltételek mellett - a végrehajtó hatóság az ENYH-ban meghatározottól eltérő nyomozási cselekményhez folyamodjon. ${ }^{59}$ Emellett természetesen az ENYH irányelv hatálya sokkal szélesebb körü, s a nyomozási cselekmények csaknem teljes skálájára ${ }^{60}$ kiterjed. ${ }^{61}$ Mindezeken túl a rendelettervezet preambuluma és 23. cikke is egyértelmüen rögzíti, hogy ez a rendelet nem képezné akadályát annak, hogy adott esetben a tagállamok hatóságai az elektronikus bizonyítékok beszerzése érdekében ENYH-t bocsássanak ki. Ennek mérlegelése az adott tagállam hatóságának hatáskörébe tartozik. Olyan ügyekben ugyanis, ahol több nyomozási cselekmény végrehajtása is szükséges, ott nyilvánvalóan indokoltabb az elektronikus bizonyítékok megszerzését is ENYH-ba foglalni. ${ }^{62}$ Mindezek mellett az e-bizonyítékok megszerzése vonatkozásában az ENYH szerepét már az Európai Parlament 2017. október 3-i állásfoglalása is megerősítette, amelyben felszólította a tagállamokat az ENYH irányelv maradéktalan végrehajtására az e-bizonyítékok hatékony biztosítása és begyűjtése érdekében. ${ }^{63}$

58 Javaslat - Az Európai Parlament és a Tanács rendelete a büntetőügybeli elektronikus bizonyítékokra vonatkozó, közlésre és megőrzésre kötelező európai határozatokról - Irányadó vita. Brüsszel, 2018. október 4.

59 ENYH irányelv 10. cikk (1)-(2) bekezdések.

60 Kivételt képez a közös nyomozó csoport létrehozása és a bizonyítékok közös nyomozó csoporton belüli összegyűjtése. Lásd ENYH irányelv (8) preambulumbekezdés, 3. cikk.

61 Javaslat - Az Európai Parlament és a Tanács rendelete a büntetőügybeli elektronikus bizonyítékokra vonatkozó, közlésre és megőrzésre kötelező európai határozatokról. Brüsszel, 2018. április 18.

62 Javaslat az Európai Parlament és a Tanács rendelete a büntetőügybeli elektronikus bizonyítékokra vonatkozó, közlésre és megőrzésre kötelező európai határozatokról. COM/2018/225 final (61) preambulumbekezdés.

63 Az Európai Parlament 2017. október 3-i állásfoglalása a kiberbűnözés elleni küzdelemről [2017/2068(INI)] HL C 346, 2018. 09. 27., 29-43. 66. pont. 


\section{Zárszó helyett}

Az ENYH megalkotását célzó törekvések megjelenésétől kezdődően számos kritikai észrevétel olvasható a vonatkozó jogi szakirodalomban. ${ }^{64} \mathrm{Az}$ egyik legvitatottabb kérdés az alapvető jogoknak és a fegyverek egyenlősége elvének az érvényesülése. Az egységes igazságszolgáltatási térség kialakítását és a büntetőeljárások hatékonyságának növelését célzó törekvésekkel valóban arányban állnak-e azok az intézkedések, amelyek a terhelt eljárási jogainak a minél szélesebb körü biztosítására irányulnak? ${ }^{65}$ A büntetőeljárások során a bizonyítási eszközök megszerzése az alapvető jogok perspektívájából igen érzékeny terület, hiszen az eljáró hatóságoknak gyakran korlátozniuk kell a terhelt alapvető jogait. Ez utóbbiak tiszteletben tartására, valamint a büntetőeljárás gyors és eredményes lefolytatására irányuló elvárások közötti konfliktus különösen jól érzékelhető az ENYH irányelv kapcsán, amelyben több ízben is találunk utalást az alapvető jogok tiszteletben tartására, ${ }^{66}$ továbbá arra, hogy az irányelvet a büntetőeljárás során az eljárási jogokról szóló irányelvek ${ }^{67}$ rendelkezéseinek figyelembevételével kell végrehajtani. ${ }^{68}$ Így egyértelműen az alapvető jogok érvényesülését szolgálja: (1) az eltérő nyomozási cselekmény alkalmazásának a lehetősége, amennyiben az ENYH-ban megjelölt intézkedéshez képest az alapvető jogokat kevésbé sértő eszköz állna rendelkezésre, (2) az ENYH igazságügyi hatóság általi jóváhagyásának kötelezettsége a kibocsátó államban, továbbá (3) a végrehajtás megtagadásának lehetősége az alapvető jogok megsértésére hivatkozással. ${ }^{69}$

Mindezek mellett természetesen az uniós jogalkotás azon termékeire is tekintettel kell lenni, amelyek az ENYH irányelv elfogadását követően keletkeztek, azonban a védelemhez való ${ }^{70}$ jogra további hivatkozás az ENYH irányelvben nem találha-

64 A kritika leginkább arra irányult, hogy a jogalkotók jobban vegyék figyelembe a nemzeti büntető igazságszolgáltatási rendszerek sajátosságait, az alapvető jogok és az arányosság elve tiszteletben tartásának követelményét, továbbá azokat a problémákat, amelyek az európai elfogatóparancs gyakorlati alkalmazása során már felmerültek. Lásd DE CAPITANI, Emilio-PEERS, Steve: The European Investigation Order: A new approach to mutual recognition in criminal matters. 23 May 2014. http://eulawanalysis.blogspot.com/2014/05/theeuropean-investigation-order-new.html (2018. 12. 02.).

65 BACHMAIER WINTER, Lorena: European investigation order for obtaining evidence in the criminal proceedings. Study of the proposal for a European directive. Zeitschrift für Internationale Strafrechtsdogmatik. 2010/9, 587. http://www.zis-online.com/dat/artikel/2010_9_490.pdf (2012. 05. 10.).

66 ENYH irányelv (12) és (19) preambulumbekezdések, 1. cikk (4) bekezdés, 11. cikk (1) bekezdés f) pont.

67 Az Európai Parlament és a Tanács 2010/64/EU irányelve (2010. október 20.) a büntetőeljárás során igénybe vehető tolmácsoláshoz és fordításhoz való jogról. HL L 280, 2010. 10. 26., 1-7; Az Európai Parlament és a Tanács 2012/13/EU irányelve (2012. május 22.) a büntetőeljárás során a tájékoztatáshoz való jogról. HL L 142, 2012. 06. 01., 1-10; Az Európai Parlament és a Tanács 2013/48/EU irányelve (2013. október 22.) a büntetőeljárás során és az európai elfogatóparancshoz kapcsolódó eljárásokban ügyvédi segítség igénybevételéhez való jogról, valamint valamely harmadik félnek a szabadságelvonáskor történő tájékoztatásához való jogról és a szabadságelvonás ideje alatt harmadik felekkel és a konzuli hatóságokkal való kommunikációhoz való jogról. HL L 294, 2013. 11. 06., 1-12.

68 ENYH irányelv (15) preambulumbekezdés.

69 Ez utóbbi esetkört lásd Ebem. tv. 40. § (1) bekezdés a) pont.

70 Nagy Anita mint a védelemhez való jog érvényesülésére hívja fel a figyelmet a terhelt és a védő ENYH kibocsátásának az indítványozására irányuló jogára, valamint jogorvoslati jogukra az ENYH kibocsátására, 
tó. ${ }^{71}$ Természetesen az, hogy milyen tényleges kérdéseket vet fel a terhelti jogok érvényesülése szempontjából az ENYH alkalmazása, ${ }^{72}$ csak hosszabb időt átívelő joggyakorlat alapján vizsgálható.

\section{Abstract}

The purpose of this article is to highlight the role of the European Investigation Order (EIO) in effective criminal procedures and criminal investigations. Moreover it aims to demonstrate how it contributes to establishing a single regime for obtaining evidence in the European Union. This article is divided into three separate parts. The first section contains a comparative analysis: how the provisions of the Directive regarding EIO were implemented in the Hungarian legal system in relation to criminal cases. The second section focuses on the main questions of the first preliminary ruling procedure related to this Directive. Finally, in the third part the relationship of EIO to other legal instruments, which are also based on mutual recognition and focused on evidence in criminal procedures is analysed.

valamint a végrehajtás során hozott határozatokra és intézkedésekre tekintettel. Megjegyzendő, hogy az előbbi indítványozási jog csak a nemzeti jogban kerül deklarálásra. Lásd NAGY Anita: Az európai nyomozási határozat a kölcsönös elismerés elve tükrében. Kúriai Döntések: Bírósági Határozatok: A Kúria Lapja. 2017/6, 866.

71 Garcimartin Montero, Regina: The European Investigation Order and the Respect for Fundamental Rights in Criminal Investigations. Eucrim: The European Criminal Law Associations' Forum, 2017/1, 45-46, 49.

72 Lényeges és véleményem szerint valós problémák körét veti fel és fejti ki Karsai Krisztina és Törő Andrea a védőnek a más tagállamban foganatosított eljárási cselekményeken való jelenléti jogával kapcsolatban. KARSAI (2012): i. m., 30-31, TÖRÖ: i. m., 16-17. 